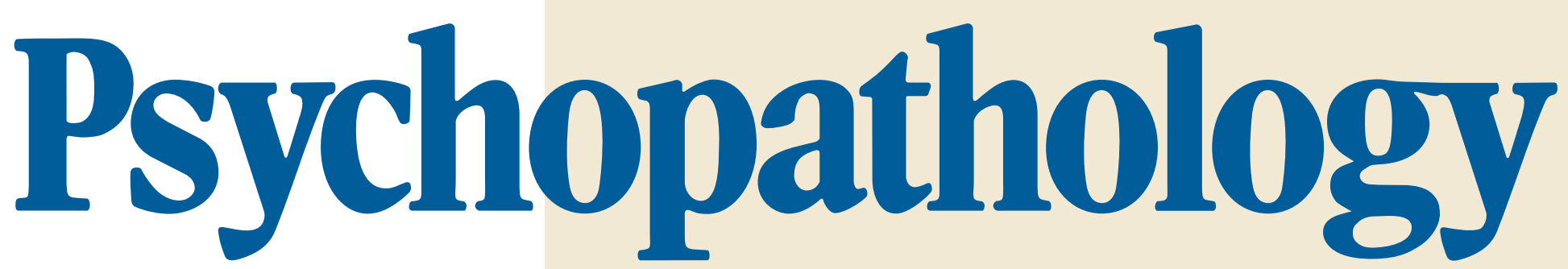

International Journal of

Descriptive and

Experimental Psychopathology,

Phenomenology and

Psychiatric Diagnosis

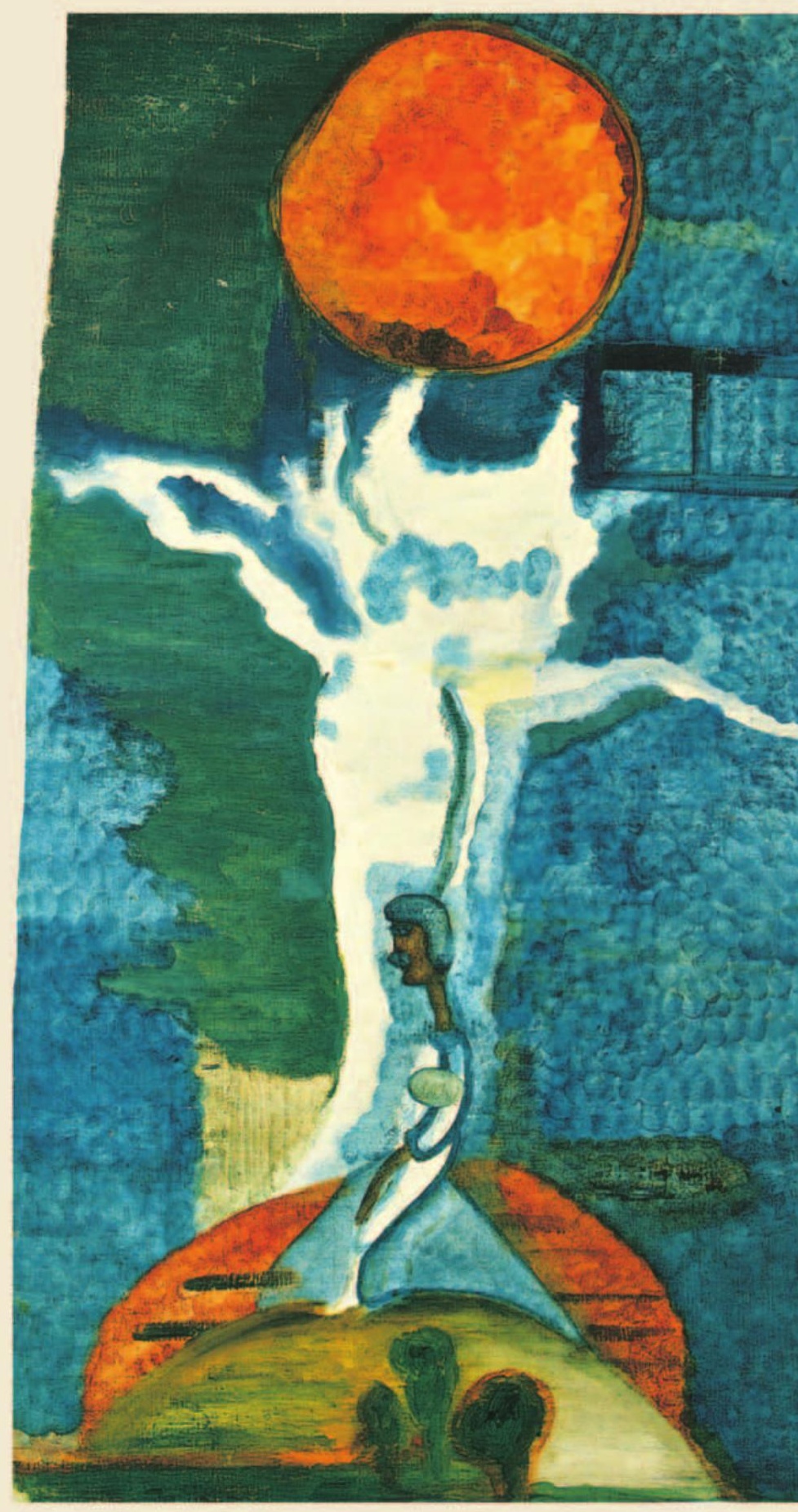




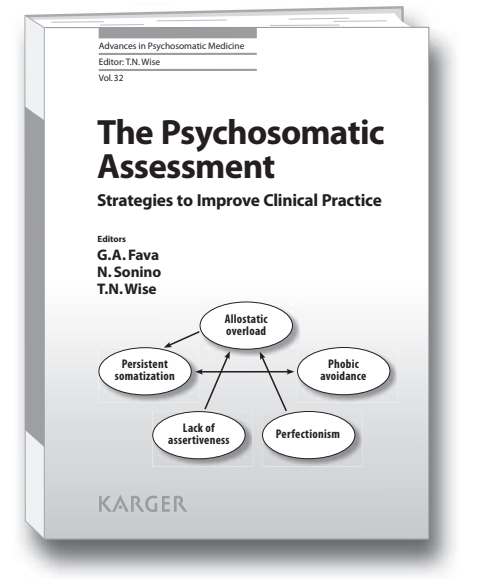

Psychosomatic medicine has developed methods to increase diagnostic accuracy and improve targeted therapeutic approaches in all fields of medicine. In this context, clinimetrics, the science of clinical measurements, provides unprecedented opportunities for psychosomatic assessment.

This volume illustrates how this approach can be translated into everyday practice complementing and improving the medical interview. The most sensitive and reliable clinical methods are presented for evaluating specific psychosocial aspects of disease, i.e. childhood adversities, life events and chronic stress, lifestyle, sexual function, subclinical and affective disturbances, personality, illness behavior, well-being and family dynamics. Each chapter provides practical illustrations as to how crucial information can be obtained with specific methods individualized according to the patients' needs. A hyperlink is provided to a website that contains many of the instruments assessed in the volume.

This book enables the reader to understand the value of the psychosomatic approach in clinical practice. It is intended to expand and refine the skills of clinicians who work in general and specialized medicine and psychiatry, whether physicians, psychologists or other health professionals.

\section{The Psychosomatic Assessment}

\author{
Strategies to Improve Clinical Practice
}

Editors
Giovanni A. Fava
Nicoletta Sonino
Thomas N. Wise

\section{Contents}

Principles of Psychosomatic Assessment: Fava, G.A.; Sonino, N.; Wise, T.N.

The Psychosomatic Interview: Wise, T.N.; Dellemonache, P.M.; Bachawati, M.M.

Evaluating Childhood Adversity: Thabrew, H.; de Sylva, S. ; Romans, S.E.

Evaluating Life Events and Chronic Stressors in Relation to Health: Stressors and Health in Clinical Work: Theorell, T.G.

Assessment of Lifestyle in Relation to Health: Tomba, E.

Assessment of Sexual Function in the Medically III: Psychosomatic Approach to Sexual Functioning: Balon, $\boldsymbol{R}$.

Psychological Factors in Medical Disorders Assessed with the Diagnostic Criteria for Psychosomatic Research: Porcelli, P.; Todarello, 0 .

www.karger.com/adpsy
Mood and Anxiety in the Medically III: Bech, $P$.

Assessment of Personality in Psychosomatic Medicine: Current Concepts: Cosci, $\boldsymbol{F}$.

Illness Behavior: Sirri, L.; Grandi, S.

Assessment of Psychological Well-Being in Psychosomatic Medicine: Rafanelli, C.; Ruini, C.

Family Assessment in the Medical Setting: Keitner, G.I.

Relational Ethics and Psychosomatic Assessment: Barbosa, $\boldsymbol{A}$.
Online supplementary material Separate free download at www.karger.com/AIP032_suppl

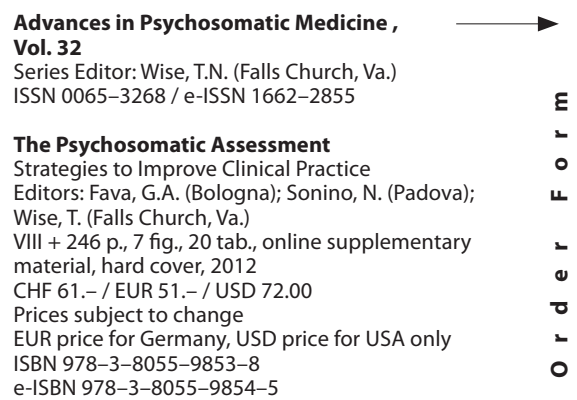

$\boldsymbol{\varepsilon}$

$-$

\section{Please send: _ copy/ies}

Postage and handling free with prepayment

Payment:

Please charge to my credit card

- $\square$ American Express $\square$ Diners $\square$ Eurocard

ᄂ $\square$ MasterCard $\square$ Visa

Card No.:

Exp. date:

- CVV/CVC

( 3 digits in the signature field on the back of Visa and MasterCard)

$\square$ Check enclosed $\square$ Please bill me

Orders may be placed with any bookshop, subscription agency, directly with the publisher or through a Karger distributor.
Fax: +41613061234

S. Karger AG, P.O. Box, CH-4009 Basel (Switzerland)

E-Mail orders@karger.ch, www.karger.com

Name/Address: 


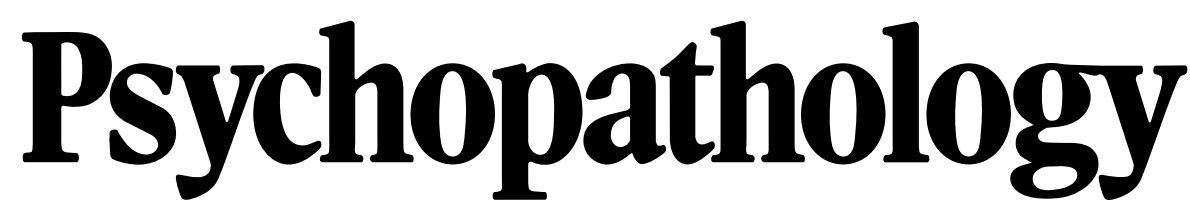

International Journal of Descriptive and Experimental Psychopathology, Phenomenology and Psychiatric Diagnosis

Founded 1897 as 'Monatsschrift für Psychiatrie und Neurologie', continued 1957-1967 as 'Psychiatria et Neurologia', continued 1968-1983 as 'Psychiatria Clinica'

Founders: C. Wernicke and Th. Ziehen

Successors: K. Bonhoeffer (1912-1938), J. Klaesi (1939-1967), E. Grünthal (1953-1973),

N. Petrilowitsch (1968-1970), Th. Spoerri (1971-1973), P. Berner (1974-1999),

E. Gabriel (1974-2004), Ch. Mundt (2000-2011)

\section{Editor-in-Chief}

S.C. Herpertz, Heidelberg

\section{Honorary Consultant Editor}

H.S. Akiskal, San Diego, Calif.

\section{Editorial Assistant}

S. Neidlein, Heidelberg

\section{Section Editors}

T. Fuchs, Heidelberg

V. Gallese, Parma

S.C. Herpertz, Heidelberg

P. McGorry, Melbourne, Vic.

\section{Editorial Board}

A. Arntz, Maastricht

D. Bhugra, London

A. Buchheim, Innsbruck

F. Caspar, Bern

A.M. Chanen, Parkville, Vic.

Y.-F. Chen, Beijing

A.S. David, London

N.M.J. Edelstyn, Keele

H. Fabisch, Graz

K. Fabisch, Graz

P. Falkai, Göttingen

H.J. Freyberger, Greifswald/ Stralsund

S.N. Ghaemi, Boston, Mass.

J.G. Gunderson, Belmont, Mass.

M. Härter, Hamburg

A. Heerlein, Santiago

P. Henningsen, München

H.P. Kapfhammer, Graz

J. Klosterkötter, Köln

M.F. Lenzenweger,

Binghamton, N.Y.

S. Löber, Heidelberg

W. Maier, Bonn

M. Maj, Naples

Ch. Mundt, Heidelberg

J. Parnas, Copenhagen
C. Reck, Heidelberg

F. Resch, Heidelberg

F. Schneider, Aachen

K. Schnell, Heidelberg

L. Siever, New York, N.Y.

K. Silk, Ann Arbor, Mich.

C. Sinigaglia, Milan

G. Stanghellini, Florence

E. Vieta, Barcelona

M. Weisbrod, Karlsbad

A.R. Yung, Parkville, Vic.
Printed in Switzerland on acid-free and non-aging paper (ISO 9706) by Reinhardt Druck, Base
Appears bimonthly: 1 volume per year (6 issues) 


\section{Psychopathology}

'Psychopathology' addresses scientists who work on descriptive psychopathology in clinical contexts, or with experimental methods in neuropsychology and experimental psychopathology, or on conceptual framing of psychopathological findings for understanding pathogenesis and for validation of diagnosis and classification. They may include an interdisciplinary approach to other medical and biological fields or to the humanities. Psychopathology does not only invite reports on medical research but also wants to address psychologists who refer to pathological phenomena or work within clinical settings. The central field of interest is the convergence of clinical phenomena, experimental findings, and conceptualisation. This would also include describing pathogenetic mechanisms of disturbed neuropsychological functions which allows remodelling and evaluation of psychotherapeutic tools.

\section{Types of Papers}

'Psychopathology' accepts papers on the four following sections: Original Paper, Review, Case Report, Short Report (up to 8 manuscript pages). Reviews may contain overviews, meta-analyses and conceptual papers based on a literature overview; Original Papers contain data generated by the authors Case Reports will only be accepted if they stimulate novel functional insights or classificatory concepts; Short Reports will also be restricted to relevant issues of scientific debate.

Submission

Only original papers written in English are considered and should be submitted using the online submission website at

\section{www.karger.com/psp}

Should you experience any problems with your submission, please contact:

\section{Shirin.Neidlein@med.uni-heidelberg.de \\ Editorial Office 'Psychopathology' \\ Zentrum für Psychosoziale Medizin \\ Klinik für Allgemeine Psychiatrie \\ Universität Heidelberg \\ Voßstr. 4 \\ D-69115 Heidelberg \\ Tel. +496221567308 \\ Fax +496221565477}

\section{Conditions}

All manuscripts are subject to editorial review. Manuscripts are received with the explicit understanding that they are not under simultaneous consideration by any other publication. Submission of an article for publication implies the transfer of the copyright from the author to the publisher upon acceptance. Accepted papers become the permanen property of 'Psychopathology' and may not be reproduced by any means, in whole or in part, without the written consent of the publisher. It is the author's responsibility to obtain permission to reproduce illustrations, tables, etc. from other publications.

\section{Arrangement}

Title page: The first page of each paper should indicate the title, the authors' names, the institute where the work was conducted, and a short title for use as running head.

Full address: The exact postal address of the corresponding author complete with postal code must be given at the bottom of the title page. Please also supply phone and fax numbers, as well as e-mail address.

Key words: Please supply 3-10 key words in English that reflect the content of the paper.

Abstract: The abstract should not exceed 30 lines and should be structured as follows: Background, Sampling and Methods, Results, and Conclusions (including study limitations).
Methods: Sampling should be described in detail so that possible selection biases may be discussed. Methods should be reported in a manner enabling easy replication.

Results: The results should be described precisely and must be separated from the discussion.

Discussion: The discussion should move along the same lines as the results and should discuss the relevant literature with regard to consistencies and inconsistencies as well as elucidate on the theoretical and practical implications of the results. Further research perspectives may be addressed, e.g. concerning clarification of inconsistencies with the literature.

Footnotes: Avoid footnotes. When essential, they are numbered consecutively and typed at the foot of the appropriate page.

Tables and illustrations: Tables and illustrations (both numbered in Arabic numerals) should be prepared on separate sheets. Tables require a heading and figures a legend, also prepared on a separate sheet. For the reproduction of illustrations, only good drawings and original photographs can be accepted; negatives or photocopies cannot be used. Due to technical reasons, figures with a screen background should not be submitted. When possible, group several illustrations on one block for reproduction (max. size $180 \times 223 \mathrm{~mm}$ ) or provide crop marks. Electronically submitted b/w half-tone and color illustrations must have a final resolution of $300 \mathrm{dpi}$ after scaling, line drawings one of 800-1200 dpi.

\section{Color illustrations}

Online edition: Color illustrations are reproduced free of charge. In the print version, the illustrations are reproduced in black and white. Please avoid referring to the colors in the text and figure legends.

Print edition: Up to 6 color illustrations per page can be integrated within the text at CHF 800.- per page.

References: In the text, identify references by Arabic numerals [in square brackets]. Material submitted for publication but not yet accepted should be noted as 'unpublished data' and not be included in the reference list. The list of references should include only those publications which are cited in the text. Do not alphabetize; number references in the order in which they are first mentioned in the text. The surnames of the authors followed by initials should be given. There should be no punctuation other than a comma to separate the authors. Preferably, please cite all authors. Abbreviate journal names according to the Index Medicus system. Also see International Committee of Medical Journal Editors: Uniform requirements for manuscripts submitted to biomedical journals (www.icmje.org).

\section{Examples}

(a) Papers published in periodicals: Sun J, Koto H, Chung KF: Interaction of ozone and allergen challenges on bronchial responsiveness and inflammation in sensitised guinea pigs. Int Arch Allergy Immunol 1997;112:191-195.

(b) Papers published only with DOI numbers:

Theoharides TC, Boucher W, Spear K: Serum interleukin-6 reflects disease severity and osteoporosis in mastocytosis patients. Int Arch Allergy Immunol DOI: 10.1159/000063858 (c) Monographs: Matthews DE, Farewell VT: Using and Understanding Medical Statistics, ed 3, revised. Basel, Karger, 1996.

(d) Edited books: Parren PWHI, Burton DR: Antibodies against HIV-1 from phage display libraries: Mapping of an immune response and progress towards antiviral immunotherapy; in Capra JD (ed): Antibody Engineering. Chem Immunol. Basel, Karger, 1997, vol 65, pp 18-56.

Reference Management Software: Use of EndNote is rec ommended for easy management and formatting of citations and reference lists.

\section{Digital Object Identifier (DOI)}

S. Karger Publishers supports DOIs as unique identifiers for articles. A DOI number will be printed on the title page of each article. DOIs can be useful in the future for identifying and citing articles published online without volume or issue information. More information can be found at www. doi.org.

\section{Supplementary Material}

Supplementary material is restricted to additional data that are not necessary for the scientific integrity and conclusion of the paper. Please note that all supplementary files will undergo editorial review and should be submitted together with the original manuscript. The Editors reserve the right to limit the scope and length of the supplementary material. Supplementary material must meet production quality standards for Web publication without the need for any modification or editing. In general, supplementary files should not exceed $10 \mathrm{MB}$ in size. All figures and tables should have titles and legends and all files should be supplied separately and named clearly. Acceptable files and formats are: Word or PDF files, Excel spreadsheets (only if the data cannot be converted properly to a PDF file), and video files (.mov, .avi, .mpeg).

\section{Author's Choice ${ }^{\mathrm{TM}}$}

With this option the author can choose to make his article freely available online against a one-time fee of CHF 3000.This fee is independent of any standard charges for supplementary pages, color images etc. which may apply. More in formation can be found at www.karger.com/authors_choice.

\section{NIH-Funded Research}

The U.S. National Institutes of Health (NIH) mandates un der the NIH Public Access Policy that final, peer-reviewed manuscripts appear in its digital database within 12 months of the official publication date. As a service to authors, Karger submits the final version of your article on your behalf to PubMed Central (PMC) immediately upon publishing. It usually receives a PMCID within approximately a month and will appear in PMC after 12 months. For those selecting our premium Author's Choice ${ }^{\mathrm{TM}}$ service, the usual embargo will be overriden, accelerating the accessibility of your work More details on NIH's Public Access Policy are available at http://publicaccess.nih.gov/policy.htm

\section{Self-Archiving}

Karger permits authors to archive their pre-prints (i.e. prerefereeing) or post-prints (i.e. final draft post-refereeing) on their personal or institution's servers, provided the following conditions are met: Articles may not be used for commercial purposes, must be linked to the publisher's version, and must acknowledge the publisher's copyright. Authors selecting Karger's Author's Choice ${ }^{\mathrm{TM}}$ feature, however, are also permitted to archive the final, published version of their article, which includes copyediting and design improvements as well as citation links.

\section{Page Charges}

There is no page charge for papers of 5 or fewer printed pages (including tables, illustrations and references). Each additional complete or partial page is charged to the author at CHF 325.-. The allotted size of a paper is equal to approx. 14 manuscript pages (including tables, illustrations and references).

\section{Proofs}

Unless indicated otherwise, proofs are sent to the corresponding author and should be returned with the least possible delay. Alterations other than the correction of printer's errors are charged to the author.

\section{Reprints}

Order forms and a price list are sent with the proofs. Order submitted after the issue is printed are subject to considerably higher prices.

\section{KARGER}

Fax +4161306 1234 E-Mail karger@karger.ch www.karger.com 


\section{Psychopathology}

ISSN Print Edition: 0254-4962

ISSN Online Edition: 1423-033X

Journal Homepage: www.karger.com/psp

Publication Data: 'Psychopathology' is published 6 times a year. Volume 45 with 6 issues appears in 2012 .

Copyright: () 2012 S. Karger AG, Basel (Switzerland). All rights reserved. No part of this publication may be translated into other languages, reproduced or utilized in any form or by any means, electronic or mechanical, including photocopying, recording, microcopying, or by any information storage and retrieval system, without permission in writing from the publisher or, in the case of photocopying, direct payment of a specified fee to the Copyright Clearance Center.

Disclaimer: The statements, opinions and data contained in this publication are solely those of the individual authors and contributors and not of the publisher and the editor(s). The appearance of advertisements in the journal is not a warranty, endorsement, or approval of the products or services advertised or of their effectiveness, quality or safety. The publisher and the editor(s) disclaim responsibility for any injury to persons or property resulting from any ideas, methods, instructions or products referred to in the content or advertisements.
Subscription Rates: Subscriptions run for a full calendar year. Prices are given per year. Personal subscription:

Print or Online

CHF 230.-

EUR 184--

USD 223.00

Print+Online combined CHF 278.-

EUR 222.-

USD 270.00

postage and handling (added to print and print+online)

CHF 40.80 Europe, CHF 60.00 Overseas

EUR 31.20

USD 56.40

Institutional subscription

Print or Online

Print+Online combined

CHF 1685.

EUR 1348.-

CHF 1854.-

USD 1636.00

postage and handling (added to print and print+online)

CHF 51.00 Europe, CHF 75.00 Overseas

EUR 39.00

USD 70.50

Airmail surcharge: CHF 51.- / USD 48.00

Discount subscription prices: Various related societies.
Back Volumes and Single Issues: Information on availability and prices of single print issues and print or electronic back volumes can be obtained from Customer Service at service@karger.ch.

Bibliographic Indices: This journal is regularly listed in bibliographic services, including Current Contents ${ }^{\circledR}$ and PubMed/MEDLINE.

Photocopying: This journal has been registered with the Copyright Clearance Center (CCC), as indicated by the code appearing on the first page of each article. For readers in the US, this code signals consent for copying of articles for personal or internal use, or for the personal or internal use of specific clients, provided that the stated fee is paid per copy directly to

Copyright Clearance Center Inc.

222 Rosewood Drive

Danvers, MA 01923 (USA)

A copy of the first page of the article must accompany payment. Consent does not extend to copying for general distribution, for promotion, for creating new works, or for resale. In these cases, specific written permission must be obtained from the copyright owner,

S. Karger AG, P.O. Box

CH-4009 Basel (Switzerland).
Subscription Orders:

Orders can be placed at agencies, bookstores, directly with the Publisher

\section{S. Karger AG}

Medical and Scientific Publishers

P.O. Box

CH-4009 Basel

Switzerland

(for courier services only:

Allschwilerstrasse 10

CH-4055 Basel)

t: +41613061111

f: +41613061234

e: karger@karger.ch

w: www.karger.com or further Karger offices

or representatives:

Germany

S. Karger GmbH

Postfach

79095 Freiburg

Deutschland

(Hausadresse: Wilhelmstrasse 20A

79098 Freiburg)

$\mathrm{t}: \quad+49761452070$

f: +497614520714

e: information@karger.de

w: www.karger.de

Japan

Karger Japan, Inc.

Shiba Daimon Asahi Bldg. 2F

1-2-23 Shiba Daimon

Minato-ku

Tokyo 105-0012

Japan

$\mathrm{t}:+81364356242$

f: +81364356244

e: publisher@karger.jp

w: www.karger.jp

Change of Address:

Both old and new address should be sent

to the subscription source.

USA

S. Karger Publishers, Inc.

26 West Avon Road

P.O. Box 529

Unionville, CT 06085

USA

Toll free: +1 8008285479

t: +18606757834

f: +18606757302

e: karger@snet.net

France

Librairie Médi-Sciences Sar

36, bd de Latour-Maubourg

75007 Paris

France

$\mathrm{t}: \quad+33(0) 145514258$

f: $+33(0) 145560780$

e: librairie@medi-sciences.f

e: librairie@medi-sciences.

Gulf Council Countries, Iran,

Middle East, North Africa, Turkey

Trans Middle East International

Distribution Co. Ltd. (KaSha)

168 B, King Abdullah the 2nd Street

Daboog Building 2nd Floor

Daboog Area

P.O. Box 2376

Amman 11953

Jordan

t: +962 65153467

f: +96265411336

e: info@kasha.cc

w: www.KaShaonline.com
South East Asia, China and Taiwan

Karger Regional Office (Malaysia)

CEO Suite Kuala Lumpur

Quill 7, 27th Floor

Jalan Stesen Sentral 5

KL Sentral

Kuala Lumpur 50470

Malaysia

t: +60327766803

f: +60327766999

e: service@karger.cn; r.chew@karger.cn

Karger China

10th Floor, Twin Towers (East)

B12 Jianguomenwai Avenue

Beijing 100022

China

$\mathrm{t}:+861051235033$

f: +861051235122

e: service@karger.cn; r.chew@karger.cn

w: www.karger.cn

India, Bangladesh, Sri Lanka

Medscience India

Plot No. 17, Yusuf Sarai Market

B.L. Glass Building, 2nd Floor

Sri Aurobindo Marg

New Delhi 110016

India

t: +911146029633

f: +911146029634

c: +919891052128

e: medsci.india@gmail.com

\section{KARGER}

Fax +41 613061234

E-Mail karger@karger.ch

www.karger.com
(C) 2012 S. Karger AG, Basel

The Journal Home Page is available at:

www.karger.com/psp 


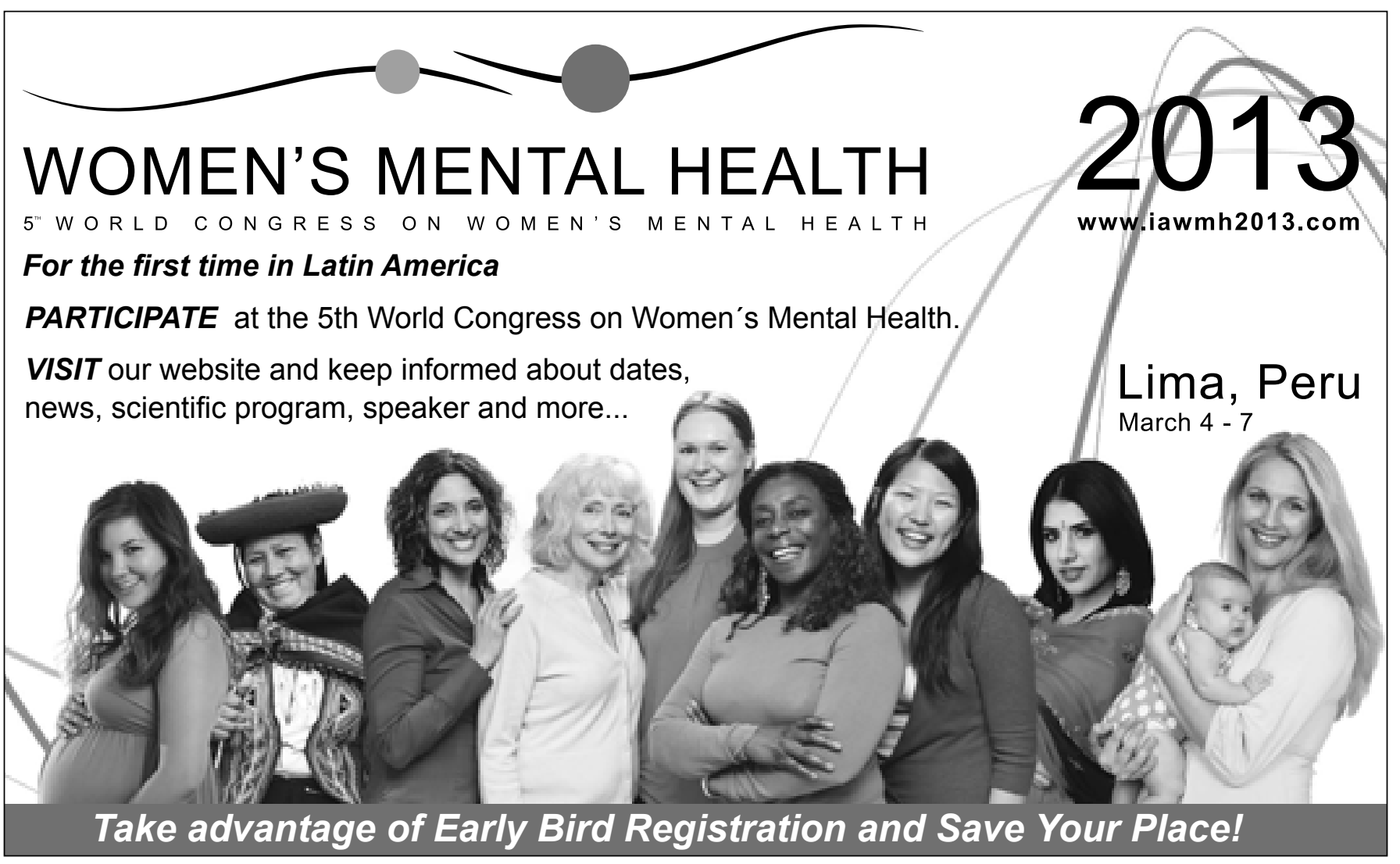

F13212

'A collection of extraordinary essays'

GOTTFRIED SCHATZ

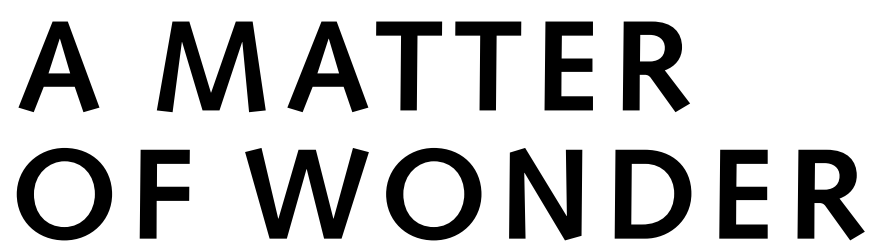

What Biology Reveals about Us, Our World, and Our Dreams

Where do we come from? Is our destiny determined by the genes we inherit? In this book Gottfried Schatz, the world-renowned biochemist and co-discoverer of mitochondrial DNA, gives lucid - albeit often surprising - answers to universal questions and takes the reader on a fascinating journey of discovery across the boundaries of scientific disciplines. With passion and a keen sense of wonder he draws on philosophy, cultural history and art to formulate his reflections on the mysteries of life. His essays will appeal not only to scientists but to all inquisitive minds, regardless of educational and professional background.

\section{KARGER (Switzerland) www.karger.com}

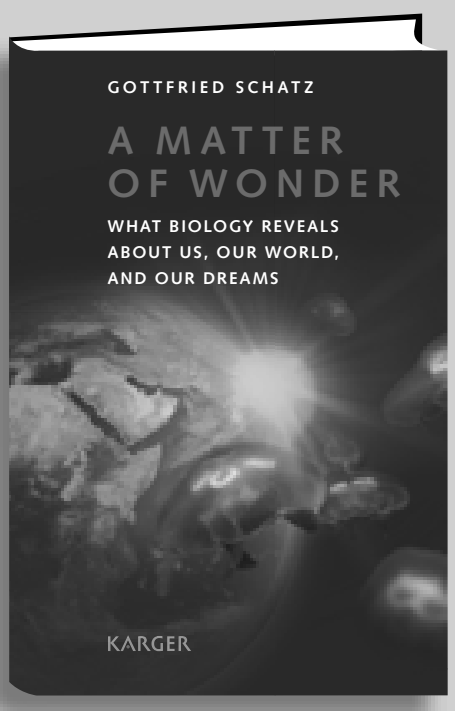

G. Schatz (Basel)

A Matter of Wonder What Biology Reveals about Us, Our World, and Our Dreams Translated by A. Shields

XII + 190 p., 2 color fig., hard cover, 2011 CHF 29.-/ EUR 21.50/USD 29.00 ISBN 978-3-8055-9744-9

More information and sample essays at www.karger.com/schatz 


\section{Contents}

See the journal website for contents

KARGER Basel $\bullet$ Freiburg $\cdot$ Paris $\bullet$ London $\bullet$ New York $\cdot$ New Delhi $•$ Bangkok Beijing $\cdot$ Tokyo $\cdot$ Kuala Lumpur $\cdot$ Singapore $\bullet$ Sydney 


\section{\& Treatment Guidance}

TERATIONAL SOCIETY Of MEUROAIOLOGY

PSYCHOPHARMACOLOGY

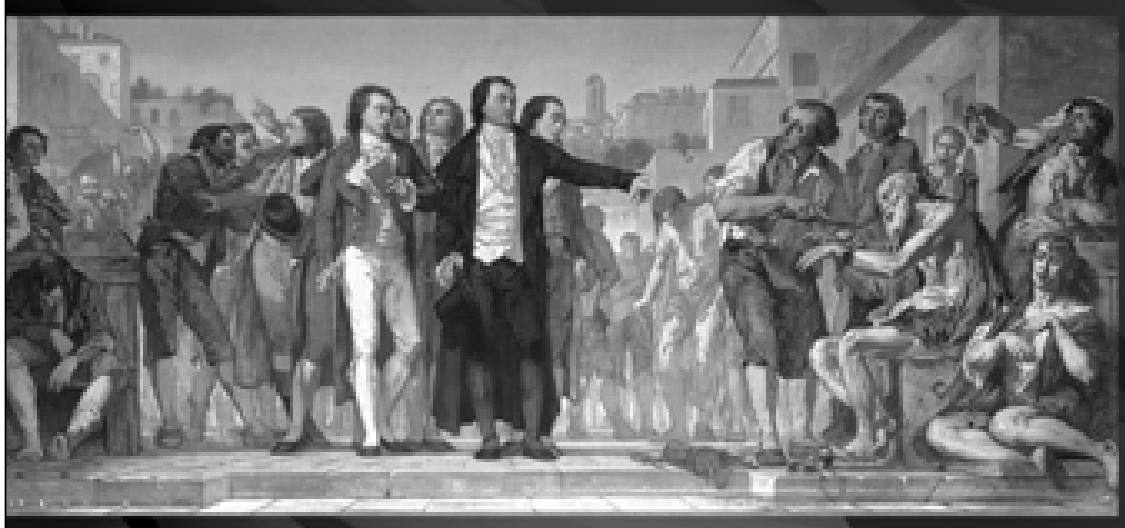

World Psychiatric Association

Will be accredited with CME credits by UEMS/EACCME

Under the auspises of:

(A) School of Medicine

9. Aristotle University of Thessaloniki, Greece

1. Hellenic Psychiatric Association

Psychiatric Association

for Eastern Europe and the Balkans

*ु) World Association for Social Psychiatry

European Psychiatric Association

\section{Key Issues in Mental Health} (formerly 'Bibliotheca Psychiatrica')

Problems of clinical psychiatry covered in a series that has helped pioneer the development of this field

With its first volume published in 1917, this series has served to chart some of the main developments of contemporary psychiatry. Throughout these years, individual volumes have outlined the specific problems and controversies which have characterized the growth of psychiatry and have reflected a broadening acceptance of its methods and applications. Recent volumes have been distinguished by their bench to bedside coverage of current topics in psychiatry, psychology and neurosciences. Taking a rigorously interdisciplinary as well as translational approach, Key Issues in Mental Health attempts to build bridges to related disciplines in an effort to integrate a variety of aspects relevant to the successful diagnosis and treatment of psychiatric disorders.

\section{Vol. 177: Neurocognition and Social Cognition in Schizophrenia Patients \\ Basic Concepts and Treatment Editors: Roder, V. (Bern); Medalia, A. (New York, N.Y.) \\ $X+176$ p., 16 fig. 1 in color, 11 tab., hard cover, 2010 \\ CHF 67.- / EUR 56. - / USD 79.00 ISBN 978-3-8055-9338-0 e-ISBN 978-3-8055-9339-7}

\section{Vol. 176: Attention-Deficit Hyperactivity Disorder (ADHD) in Adults \\ Editors: Retz, W. (Homburg/Saar); Klein, R.G. (New York, N.Y.) $\mathrm{VIII}+192$ p., 9 fig., 18 tab., hard cover, 2010 \\ CHF 69.- / EUR 58.- / USD 81.00 \\ ISBN 978-3-8055-9237-6 e-ISBN 978-3-8055-9238-3}

\section{Vol. 175: The Menopausal}

\section{Transition}

Interface between Gynecology and

Psychiatry

Editors: Soares, C.N. (Hamilton, Ont.); Warren, M. (New York, N.Y.)

VIII + 150 p., 9 fig., 4 in color, 5 tab.,

hard cover, 2009

CHF 64.- / EUR 53.- / USD 75.00

ISBN 978-3-8055-9101-0

e-ISBN 978-3-8055-9102-7

\section{Vol. 174: Stress}

The Brain-Body Connection Editors: Hellhammer, D.H.; Hellhammer, J. (Trier)

VIII + 108 p., 3 fig., hard cover, 2008 CHF 42. - / EUR 35. - / USD 49.00 ISBN 978-3-8055-8295-7 e-ISBN 978-3-8055-7969-8 


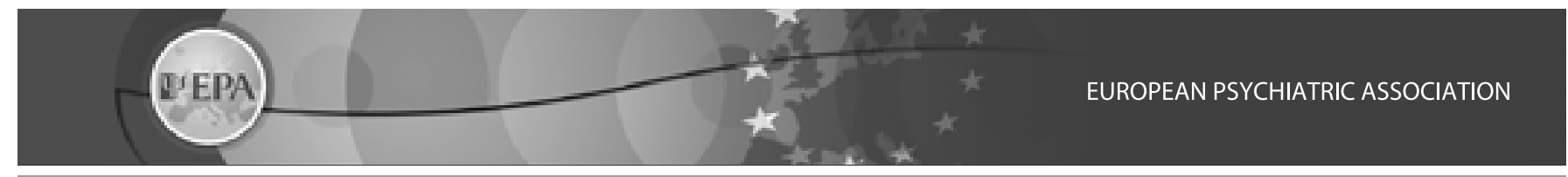

\section{Europe Challenges the Burden of Mental Disorders}

$21^{\text {st }}$ EUROPEAN

CONGRESS OF PSYCHIATRY

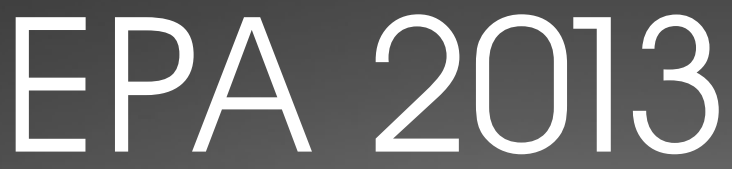

Nice, France 6-9 April 2013
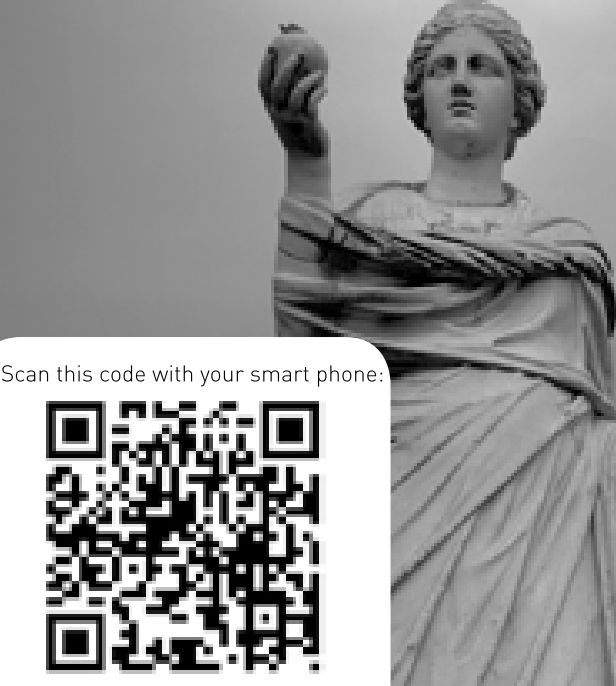

Need a code reader tor your pho

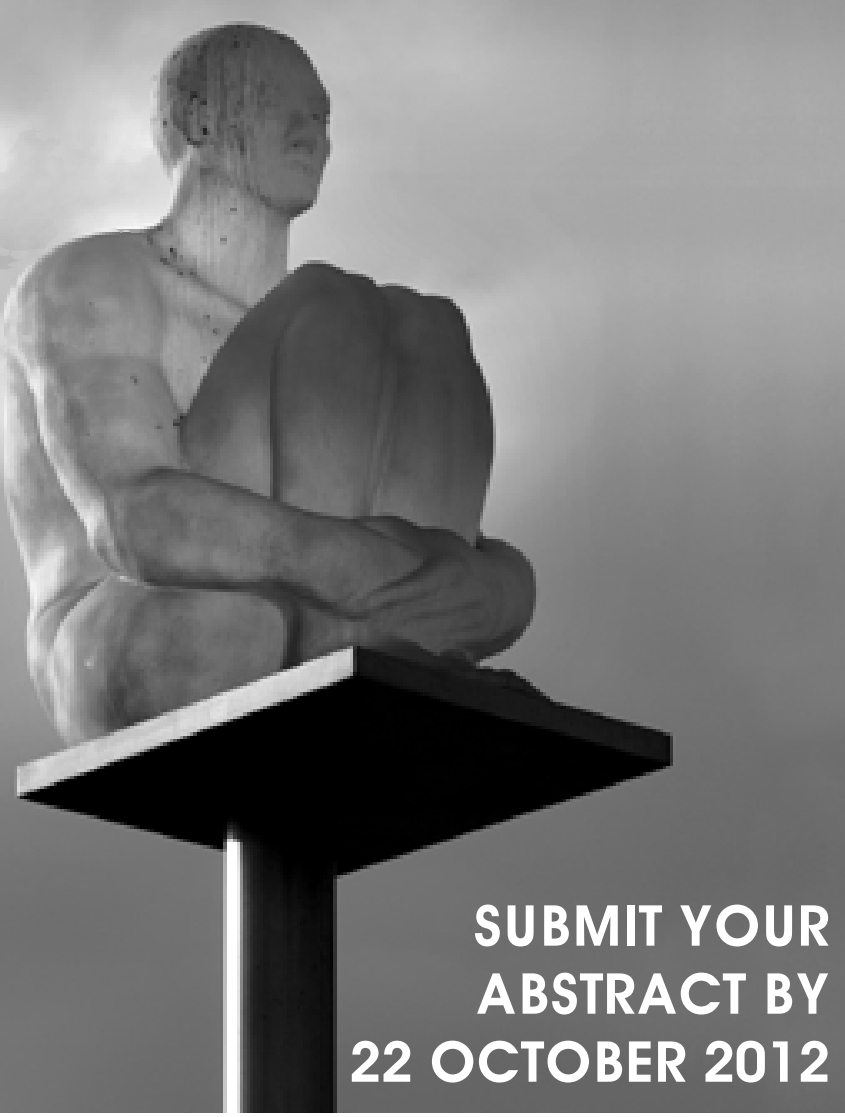

www.epa-congress.org 


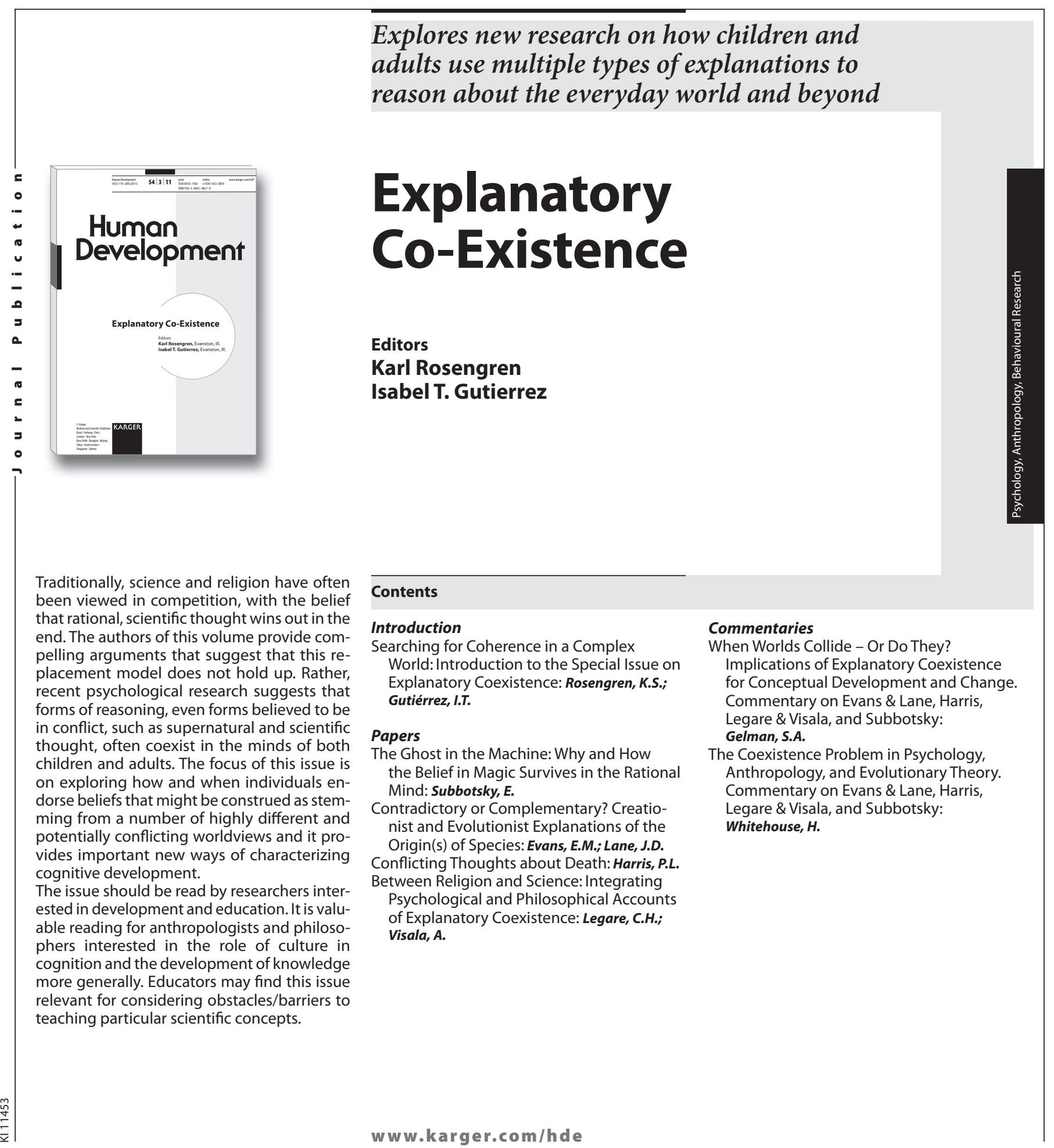

Explanatory Co-Existence
Editors: Rosengren, K. (Evanston, III.); Gutierrez, I.T.

(Evanston, III.)

82 p., 5 fig., 1 tab., soft cover, 2011

82 p., 5 fig., 1 tab., soft cover, 2011
CHF 39.- / EUR 33.- / USD 46.00

Prices subject to change

EUR price for Germany, USD price for USA only

ISBN 978-3-8055-9827-9

e-ISBN 978-3-8055-9828-6

Special Topic Issue:

Human Development

Vol. 54, No. 3 (2011)

Included in subscription

\section{KARGER}

Explores new research on how children and adults use multiple types of explanations to reason about the everyday world and beyond

ww w.karger.com/hde

\section{mmentaries}

Implications of Explanatory Coexistence for Conceptual Development and Change. Commentary on Evans \& Lane, Harris, Legare \& Visala, and Subbotsky: Legare \& Visala, and Subbotsky: Whitehouse, $\boldsymbol{H}$.

\section{Please send: copy/ies}

E Payment:

Please charge to my credit card

- $\square$ American Express $\square$ Diners $\square$ Eurocard

ᄂ $\square$ MasterCard

Card No.:

Exp. date:

- CVV/CVC

( 3 digits in the signature field on the back of Visa and MasterCard)

$\square$ Check enclosed $\square$ Please bill me

Orders may be placed with any bookshop, subscription agency, directly with the publisher or through a Karger distributor.
Fax: +41613061234

S. Karger AG, P.O. Box, CH-4009 Basel (Switzerland) E-Mail orders@karger.ch,www.karger.com

Name/Address:

Date: 


\section{Psychopathology}

Reviews

337 Reduplicative Paramnesia: A Review

Politis, M.; Loane, C. (London)

344 Logic Structure of Clinical Judgment and Its Relation to Medical and Psychiatric Semiology

Rejón Altable, C. (Madrid)

Original Papers

352 The Effect of Simulated Auditory Hallucinations on Daily Activities in Schizophrenia Patients

Han, K.; Heo, J.-K.; Seo, S.-O.; Hong, M.-Y.; Lee, J.S.; Shin, Y.S. (Seoul); Ku, J. (Daegu); Kim, S.I.; Kim, J.-J. (Seoul)

361 Examining the Overlap between Bipolar Disorder, Nonaffective Psychosis, and Common Mental Disorders Using Latent Class Analysis

Vaidyanathan, U. (Minneapolis, Minn.); Patrick, C.J. (Tallahassee, Fla.); Iacono, W.G.

(Minneapolis, Minn.)

366 Attempted Suicide in Immigrants from Turkey: A Comparison with Swiss Suicide Attempters

Yilmaz, A.T. (Istanbul); Riecher-Rössler, A. (Basel)

374 Self-Reported Psychotic Symptoms in the General Population: Correlates in an Iranian Urban Area

Sharifi, V.; Bakhshaie, J.; Hatmi, Z.; Faghih-Nasiri, L.; Sadeghianmehr, Z.; Mirkia, S.; Darbooy, S.; Effatpanah, M.; Mirsharifa, S.M. (Tehran)

381 Diagnostic Efficiency of the German Version of the Self-Rated Standardized Assessment of Personality - Abbreviated Scale

Söchtig, A.; Kliem, S.; Kröger, C. (Brunswick)

390 Discriminative Hypomania Checklist-32 Factors in Unipolar and Bipolar Major Depressive Patients

Perugi, G. (Pisa); Fornaro, M. (Genoa); Maremmani, I. (Pisa); Canonico, P.L. (Novara);

Carbonatto, P. (Turin); Mencacci, C. (Milan); Muscettola, G. (Naples); Pani, L. (Cagliari); Torta, R (Turin); Vampini, C. (Verona); Parazzini, F.; Dumitriu, A. (Milan); Angst, J. (Zurich) on behalf of Come To Me Study Group

Letter to the Editor

399 The Impact of Consanguinity on Risk of Schizophrenia Bener, A. (Doha/Manchester); Dafeeah, E.E.; Samson, N. (Doha)

401 Acknowledgement to Reviewers

after 402 Contents Vol. 45, 2012 